Article

\title{
Varespladib (LY315920) and Methyl Varespladib (LY333013) Abrogate or Delay Lethality Induced by Presynaptically Acting Neurotoxic Snake Venoms
}

\author{
José María Gutiérrez ${ }^{1, *(\mathbb{C})}$, Matthew R. Lewin ${ }^{2,3}$, David. J. Williams ${ }^{4}$ (D) and Bruno Lomonte ${ }^{1}$ \\ 1 Instituto Clodomiro Picado, Facultad de Microbiología, Universidad de Costa Rica, San José 11501-2060, \\ Costa Rica; bruno.lomonte@ucr.ac.cr \\ 2 Ophirex, Inc., Corte Madera, CA 94925, USA; matt@ophirex.com \\ 3 California Academy of Sciences, San Francisco, CA 94118, USA \\ 4 Global Snakebite Initiative, Ashgrove Qld 4060, Australia; dr_davidwilliams@outlook.com \\ * Correspondence: jose.gutierrez@ucr.ac.cr; Tel.: +506-2511-7865
}

Received: 1 February 2020; Accepted: 18 February 2020; Published: 20 February 2020

check for updates

\begin{abstract}
The phospholipase $\mathrm{A}_{2}\left(\mathrm{PLA}_{2}\right)$ inhibitor Varespladib (LY315920) and its orally bioavailable prodrug, methyl-Varespladib (LY333013) inhibit PLA $_{2}$ activity of a wide variety of snake venoms. In this study, the ability of these two forms of Varespladib to halt or delay lethality of potent neurotoxic snake venoms was tested in a mouse model. The venoms of Notechis scutatus, Crotalus durissus terrificus, Bungarus multicinctus, and Oxyuranus scutellatus, all of which have potent presynaptically acting neurotoxic $\mathrm{PLA}_{2} \mathrm{~S}$ of variable quaternary structure, were used to evaluate simple dosing regimens. A supralethal dose of each venom was injected subcutaneously in mice, followed by the bolus intravenous (LY315920) or oral (LY333013) administration of the inhibitors, immediately and at various time intervals after envenoming. Control mice receiving venom alone died within $3 \mathrm{~h}$ of envenoming. Mice injected with O. scutellatus venom and treated with LY315920 or LY333013 survived the $24 \mathrm{~h}$ observation period, whereas those receiving C. d. terrificus and B. multicinctus venoms survived at $3 \mathrm{~h}$ or $6 \mathrm{~h}$ with a single dose of either form of Varespladib, but not at $24 \mathrm{~h}$. In contrast, mice receiving $N$. scutatus venom and then the inhibitors died within $3 \mathrm{~h}$, similarly to the control animals injected with venom alone. LY315920 was able to reverse the severe paralytic manifestations in mice injected with venoms of O. scutellatus, B. multicinctus, and C. d. terrificus. Overall, results suggest that the two forms of Varespladib are effective in abrogating, or delaying, neurotoxic manifestations induced by some venoms whose neurotoxicity is mainly dependent on presynaptically acting PLA $_{2} \mathrm{~s}$. LY315920 is able to reverse paralytic manifestations in severely envenomed mice, but further work is needed to understand the significance of species-specific differences in animal models as they compare to clinical syndromes in human and for potential use in veterinary medicine.
\end{abstract}

Keywords: Varespladib; LY315920; LY333013; phospholipase A2; neurotoxicity; lethality

Key Contribution: Herein it is shown that low molecular mass inhibitors of secretory $\mathrm{PLA}_{2} \mathrm{~s}$ abrogate or delay lethality induced by three neurotoxic snake venoms, underscoring the potential of these inhibitors to counteract $\mathrm{PLA}_{2}$-dependent venom toxicity.

\section{Introduction}

Snakebite envenoming is a neglected tropical disease that kills or maims hundreds of thousands of people every year, especially in impoverished rural communities of sub-Saharan Africa, Asia, Latin America, and parts of Oceania [1]. Owing to the heavy impact that this disease has on global public health, the World Health Organization (WHO) launched an integrated strategy to significantly reduce 
the burden of these envenomings earlier last year [2]. One of the four pillars of this global strategy is to "ensure that safe, effective, affordable, accessible treatments for snakebite envenoming are available to all the people who need them" [2].

The centerpiece in the therapy of snakebite envenoming is the timely administration of safe and effective antivenoms [1,3]. If well-designed and manufactured following good manufacturing practices (GMPs), antivenoms are quite effective and safe, especially for controlling the life-threatening systemic effects of envenomings [3]. Nevertheless, one drawback of antivenom therapy is that it needs to be provided by trained healthcare staff in appropriately equipped clinical facilities. This becomes an issue when people have to travel long distances to reach health posts, or when antivenoms are not available in rural facilities. An unmet need is for the development of novel therapies that could be administered in the field rapidly after the onset of envenoming [4], as well as to augment antivenom performance where specific toxins have become inaccessible to antivenom upon distribution into the tissues, but might be amenable to inhibition or dislodgement by smaller molecules. Promising developments in this area have emerged, including natural and synthetic inhibitors of snake venom metalloproteinases (SVMPs) [5,6], phospholipases $\mathrm{A}_{2}\left(\mathrm{PLA}_{2} \mathrm{~s}\right)$ [7], cytotoxins of the three finger toxin family [8,9], and $\alpha$-neurotoxins [10], among others.

A promising $\mathrm{sPLA}_{2}$ inhibitor candidate with characteristics potentially filling some of these unmet needs is Varespladib (LY315920) and its orally available form methyl-Varespladib (LY333013). These inhibitors were developed by the pharmaceutical industry for the treatment of inflammatory syndromes such as sepsis, rheumatoid arthritis, and for acute manifestations of cardiovascular disease [11,12]. These avenues were abandoned following phase II or phase III clinical trials for these diseases, but these inhibitors could be repositioned for the therapy of snakebite envenoming owing to their broad ability to inhibit snake venom $\mathrm{PLA}_{2} \mathrm{~s}$ [7]. These enzymes are abundant and toxicologically relevant components in many snake venoms of high medical impact [13-17]. Following the initial description of Varespladib's capacity to inhibit PLA 2 activity of many snake venoms in vitro [7], further studies demonstrated its ability to abrogate lethality in mouse and pig models of envenoming by the venoms of the elapid snakes Oxyuranus scutellatus and Micrurus fulvius, respectively, whose neurotoxic effect is based predominantly on the action of presynaptically acting neurotoxic $\mathrm{PLA}_{2} \mathrm{~s}[18,19]$. Furthermore, Varespladib was effective in the inhibition of myotoxicity induced by crude venoms and isolated PLA $2 \mathrm{~S}$ of viperid and elapid species [20,21]. This drug was reported to inhibit the in vitro coagulotoxic effects of venoms of African spitting cobras [22].

Four crude venoms containing potent presynaptically acting neurotoxic $\mathrm{PLA}_{2} \mathrm{~s}$ of differing quaternary structure were selected to test the ability of Varespladib to abrogate, delay, or reverse neurotoxic venom effects. The four venoms selected were: Notechis scutatus, Bungarus multicinctus, Crotalus durissus terrificus, and Oxyuranus scutellatus. Varespladib's two forms, administered intravenously (i.v.) as a single rapid bolus of LY315920 (drug) or orally as LY333013 (prodrug) following experimental envenoming, abrogated or delayed lethality and reversed paralysis in three out of four venoms.

\section{Results}

\subsection{Estimation of $L D_{50} S$}

The values of $\mathrm{LD}_{50}$ of the venoms, in 18-20 g mice by the s.c. route of injection, were: N. scutatus: $4.5 \mu \mathrm{g}(95 \%$ confidence limits: $1.8-7.1 \mu \mathrm{g})$; C.d. terrificus: $7.9 \mu \mathrm{g}$ (95\% confidence limits: $4.8-11.6 \mu \mathrm{g})$, and B. multicinctus: $3.1 \mu \mathrm{g}$ (95\% confidence limits: $1.3-5.2 \mu \mathrm{g})$. The value of $\mathrm{LD}_{50}$ of the batch of O. scutellatus venom used in this study had been previously estimated as $0.012 \mu \mathrm{g} / \mathrm{g}(95 \%$ confidence limits: $0.004-0.023 \mu \mathrm{g} / \mathrm{g}$ ) [23], i.e., $0.24 \mu \mathrm{g}$ per $20 \mathrm{~g}$ mice (95\% confidence limits: $0.08-0.46 \mu \mathrm{g})$.

\subsection{Rescue Experiments}

Mice received s.c. injections of doses of venoms corresponding to $3 \mathrm{LD}_{50}$ s for N. scutatus, C.d. terrificus, and B. multicinctus, and either $3 \mathrm{LD}_{50}$ s or $12 \mathrm{LD}_{50}$ s for O. scutellatus. Then, either LY315920 or LY333013 
were administered using various schedules, as described in Materials and Methods. In the case of $N$. scutatus, co-administration or delayed administration of the inhibitors did not prolong the survival time of envenomed mice and both venom control group and groups treated with the drugs died within 2-3 h (Table 1). In contrast, when N. scutatus venom was pre-incubated with LY315920 prior to injection in mice, the lethal effect was significantly delayed; mice injected with venom alone died within 2-3 h, whereas those receiving venom pre-incubated with LY315920 died between 10 and $15 \mathrm{~h}$.

Table 1. Mortality at $3 \mathrm{~h}$ of mice injected with Notechis scutatus venom and treated with Varespladib (LY315920 or LY333013) (VAR) at various time intervals ${ }^{\text {a }}$.

\begin{tabular}{cc}
\hline Treatment & Deaths/Total at $\mathbf{3 ~ h}$ \\
\hline Venom + PBS & $4 / 4$ \\
Venom + VAR (0 min) & $4 / 4$ \\
Venom + VAR (60 min) & $4 / 4$ \\
Venom + VAR (0 min and 60 min) & $4 / 4$ \\
\hline
\end{tabular}

a Groups of four mice received three $\mathrm{LD}_{50} \mathrm{~s}$ of venom by the subcutaneous route and then, at the time intervals indicated, they were injected with either PBS i.v. (controls), LY315920 $(10 \mathrm{mg} / \mathrm{kg})$ by the i.v. route, or received LY333013 $(10 \mathrm{mg} / \mathrm{kg})$ by the oral route. Deaths were recorded at $3 \mathrm{~h}$. Identical results were obtained for treatments with both forms of Varespladib.

When mice were injected with $C$. $d$. terrificus venom, control mice died within $3 \mathrm{~h}$, whereas regardless of whether they received (a) LY315920 intravenously or (b) LY333013 orally at any time point, with or without redosing at $240 \mathrm{~min}$, treated mice survived for $3 \mathrm{~h}$ and $6 \mathrm{~h}$ but were all dead at $24 \mathrm{~h}$ (Table 2).

Table 2. Mortality at $3 \mathrm{~h}, 6 \mathrm{~h}$, and $24 \mathrm{~h}$ of mice injected with Crotalus $d$. terrificus venom and treated with Varespladib (LY315920 or LY333013) (VAR) at various time intervals ${ }^{\text {a }}$.

\begin{tabular}{cccc}
\hline Treatment & Deaths/Total at $\mathbf{3 ~ h}$ & Deaths/Total at $\mathbf{6} \mathbf{h}$ & Deaths/Total at 24 h \\
\hline Venom + PBS & $4 / 4$ & & \\
Venom + VAR (0 min) & $0 / 4$ & $0 / 4$ & $4 / 4$ \\
Venom + VAR (60 min) & $0 / 4$ & $0 / 4$ & $4 / 4$ \\
Venom + VAR (0 min and 240 min) & $0 / 4$ & $0 / 4$ & $4 / 4$ \\
Venom + VAR (60 min and 240 min) & $0 / 4$ & $0 / 4$ & $4 / 4$ \\
\hline
\end{tabular}

${ }^{a}$ Groups of four mice received three $\mathrm{LD}_{50} \mathrm{~s}$ of venom by the subcutaneous route and then, at the time intervals indicated, they were injected with either PBS i.v. (controls), LY315920 $(10 \mathrm{mg} / \mathrm{kg})$ by the i.v. route, or received LY333013 $(10 \mathrm{mg} / \mathrm{kg})$ by the oral route. Deaths were recorded at $3 \mathrm{~h}, 6 \mathrm{~h}$, and $24 \mathrm{~h}$. Identical results were obtained at the various times of observation for treatments with both forms of Varespladib.

Mice envenomed with $B$. multicinctus venom had a different response depending on whether they received LY315920 or LY333013. Venom control group animals all died within $3 \mathrm{~h}$. When LY315920 was provided i.v., mice receiving (a) the drug immediately, or (b) an immediate dose of drug and a repeat dose at $240 \mathrm{~min}$, survived at $3 \mathrm{~h}$, but three out of four were dead by $6 \mathrm{~h}$, and none of them survived by $24 \mathrm{~h}$ (Table 3). In contrast, when LY333013 was administered orally either (a) immediately, or (b) as an immediate dose with a repeat dose at $240 \mathrm{~min}$, all of them survived at $3 \mathrm{~h}$ and $6 \mathrm{~h}$, but not at $24 \mathrm{~h}$ (Table 4). For both LY315920 and LY333013 delayed administration for $60 \mathrm{~min}$, with or without redosing at $240 \mathrm{~min}$, resulted in survival at $3 \mathrm{~h}$ and $6 \mathrm{~h}$ followed by death at $24 \mathrm{~h}$ in all test animals (Tables 3 and 4). 
Table 3. Mortality at $3 \mathrm{~h}, 6 \mathrm{~h}$, and $24 \mathrm{~h}$ of mice injected with Bungarus multicinctus venom and treated with Varespladib (LY315920) (VAR) i.v. at various time intervals ${ }^{\text {a }}$.

\begin{tabular}{cccc}
\hline Treatment & Deaths/Total at $\mathbf{3} \mathbf{h}$ & Deaths/Total at $\mathbf{6} \mathbf{h}$ & Deaths/Total at 24 $\mathbf{~}$ \\
\hline Venom + PBS & $4 / 4$ & & \\
Venom + VAR (0 min) & $0 / 4$ & $\frac{3}{4}$ & $4 / 4$ \\
Venom + VAR (60 min) & $0 / 4$ & $0 / 4$ & $4 / 4$ \\
Venom + VAR (0 min and 240 min) & $0 / 4$ & $\frac{3}{4}$ & $4 / 4$ \\
Venom + VAR (60 min and 240 min) & $0 / 4$ & $0 / 4$ & $4 / 4$ \\
\hline
\end{tabular}

${ }^{a}$ Groups of four mice received three $\mathrm{LD}_{50} \mathrm{~s}$ of venom by the subcutaneous route and then, at the time intervals indicated, they were injected with either PBS i.v. (controls) or LY315920 $(10 \mathrm{mg} / \mathrm{kg})$ by the i.v. route. Deaths were recorded at $3 \mathrm{~h}, 6 \mathrm{~h}$, and $24 \mathrm{~h}$.

Table 4. Mortality at $3 \mathrm{~h}, 6 \mathrm{~h}$, and $24 \mathrm{~h}$ of mice injected with Bungarus multicinctus venom and treated with Varespladib (LY333013) (VAR) orally at various time intervals ${ }^{\text {a }}$.

\begin{tabular}{cccc}
\hline Treatment & Deaths/Total at $\mathbf{3} \mathbf{h}$ & Deaths/Total at $\mathbf{6} \mathbf{h}$ & Deaths/Total at $\mathbf{2 4} \mathbf{h}$ \\
\hline Venom + PBS & $4 / 4$ & & \\
Venom + VAR (0 min) & $0 / 4$ & $0 / 4$ & $4 / 4$ \\
Venom + VAR (60 min) & $0 / 4$ & $0 / 4$ & $4 / 4$ \\
Venom + VAR (0 min and 240 min) & $0 / 4$ & $0 / 4$ & $4 / 4$ \\
Venom + VAR (60 min and 240 min) & $0 / 4$ & $0 / 4$ & $4 / 4$ \\
\hline
\end{tabular}

${ }^{a}$ Groups of four mice received three $\mathrm{LD}_{50} \mathrm{~s}$ of venom by the subcutaneous route and then, at the time intervals indicated, they were injected with either PBS i.v. (controls), or received LY333013 (10 mg/kg) by the oral route. Deaths were recorded at $3 \mathrm{~h}, 6 \mathrm{~h}$, and $24 \mathrm{~h}$.

Control mice injected with three $\mathrm{LD}_{50} \mathrm{~s}$ of $O$. scutellatus venom died within $6 \mathrm{~h}$, whereas those receiving $12 \mathrm{LD}_{50} \mathrm{~s}$ died within $3 \mathrm{~h}$. All mice injected with three $\mathrm{LD}_{50} \mathrm{~s}$ of venom, followed by either i.v. LY315920 or oral LY333013 administered (a) immediately, or at (b) $30 \mathrm{~min}$, (c) $60 \mathrm{~min}$, (d) $90 \mathrm{~min}$, or (e) immediately and again at $240 \mathrm{~min}$ after venom injection survived the $24 \mathrm{~h}$ observation period. When mice were challenged with $12 \mathrm{LD}_{50} \mathrm{~s}$ of this venom, those receiving the inhibitors immediately or at $30 \mathrm{~min}, 60 \mathrm{~min}$, or immediately and again at $240 \mathrm{~min}$ survived for $24 \mathrm{~h}$, with the exception of one mouse treated with LY315920 at $60 \mathrm{~min}$ (Table 5). When the administration of inhibitors was delayed for $90 \mathrm{~min}$, mice survived at $3 \mathrm{~h}$ and $6 \mathrm{~h}$, but were dead by $24 \mathrm{~h}$ (Table 5). Since the inhibitors provided full protection during $24 \mathrm{~h}$ in the case of O. scutellatus venom, the $\operatorname{ID}_{50}$ of LY315920 (i.v.), was estimated in conditions when the inhibitor was injected immediately after the s.c. injection of $12 \mathrm{LD}_{50} \mathrm{~s}$ of venom. In these conditions, the $\mathrm{ID}_{50}$ was $5.94 \mathrm{mg} / \mathrm{kg}$ (95\% confidence limits: $4.36-9.46$ $\mathrm{mg} / \mathrm{kg}$ ). All mice survived the $24 \mathrm{~h}$ observation period with a dose of inhibitor of $10 \mathrm{mg} / \mathrm{kg}$.

Table 5. Mortality at $3 \mathrm{~h}, 6 \mathrm{~h}$, and $24 \mathrm{~h}$ of mice injected with Oxyuranus scutellatus venom and treated with Varespladib (LY315920 or LY333013) (VAR) at various time intervals ${ }^{\text {a }}$.

\begin{tabular}{cccc}
\hline Treatment & Deaths/Total at $\mathbf{~ h ~}$ & Deaths/Total at $\mathbf{6} \mathbf{h}$ & Deaths/Total at 24 h \\
\hline Venom + PBS & $4 / 4$ & & \\
Venom + VAR (0 min) & $0 / 4$ & $0 / 4$ & $0 / 4$ \\
Venom + VAR (30 min) & $0 / 4$ & $0 / 4$ & $0 / 4$ \\
Venom + VAR (60 min) & $0 / 4$ & $0 / 4$ & $1 / 4(0 / 4)$ \\
Venom + VAR (90 min) & $0 / 4$ & $0 / 4$ & $4 / 4$ \\
Venom + VAR (0 min and 240 min) & $0 / 4$ & $0 / 4$ & $0 / 4$ \\
\hline
\end{tabular}

${ }^{a}$ Groups of four mice received $12 \mathrm{LD}_{50} \mathrm{~s}$ of venom by the subcutaneous route and then, at the time intervals indicated, they were injected with either PBS i.v. (controls), LY315920 $(10 \mathrm{mg} / \mathrm{kg})$ by the i.v. route, or received LY333013 $(10 \mathrm{mg} / \mathrm{kg})$ by the oral route. Deaths were recorded at $3 \mathrm{~h}, 6 \mathrm{~h}$, and $24 \mathrm{~h}$. When only one deaths/total mice ratio is presented, it means that identical results were obtained when the inhibitor was administered i.v. (LY315920) or orally (LY333013). ${ }^{\text {b }}$ At 24 h, one out of four mice died in the group treated with LY315920 i.v., whereas no mice died in the group treated with LY333013 orally. 


\subsection{Reversion of Paralytic Effects}

The ability of a single bolus dose of LY315920 (10 mg/kg) to reverse the manifestations of envenoming at a time when mice showed toxicity grades of 2 or 3 (see Materials and Methods for explanation) was assessed for the venoms of $C$. d. terrificus, B. multicinctus, and O. scutellatus. The venom of $N$. scutatus was not tested since the inhibitors were unable to delay lethality in rescue experiments. As shown in Figures 1-3, there was a complete reversion of the paralytic manifestations caused by these three venoms. In the case of $C$. $d$. terrificus venom, paralysis recurred by $6 \mathrm{~h}$ and was severe by $8 \mathrm{~h}$. In contrast, in the cases of B. multicinctus and O. scutellatus venoms, animals were devoid of paralytic manifestations for $8 \mathrm{~h}$ after treatment (Figures 2 and 3).

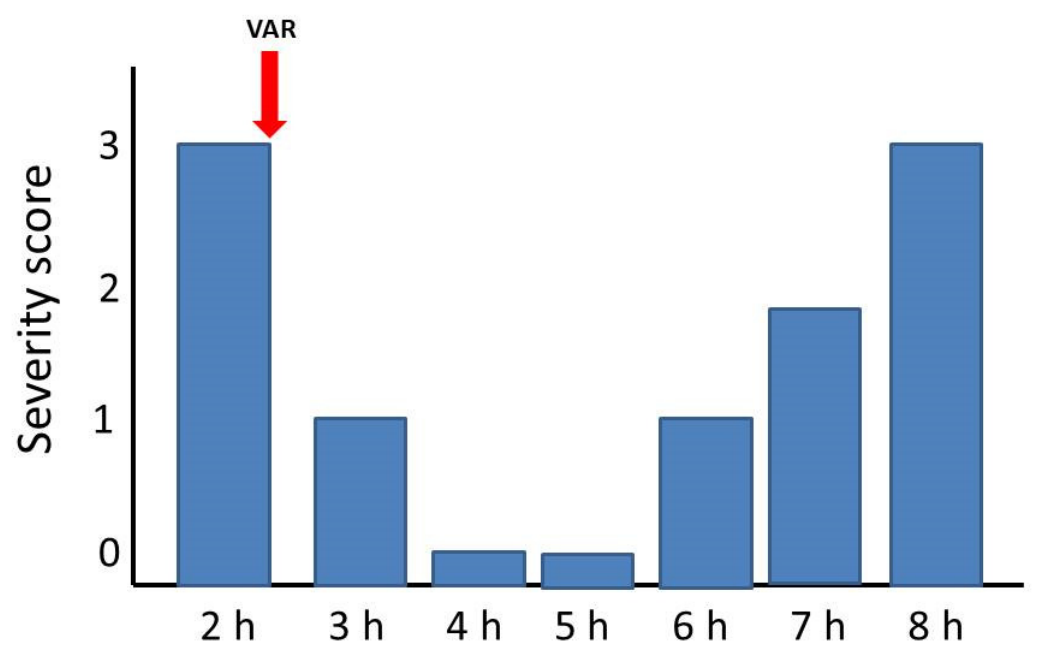

Figure 1. Reversion of paralytic manifestations in groups of four mice receiving three $\mathrm{LD}_{50} \mathrm{~s}$ of Crotalus d. terrificus venom by the subcutaneous route. A single bolus dose of LY315920 (10 mg/kg i.v.) (VAR) was administered at the time indicated by the red arrow, when mice showed paralytic manifestations corresponding to a severity score of 3 . Paralysis was reversed for the following $3 \mathrm{~h}$ and returned afterwards.

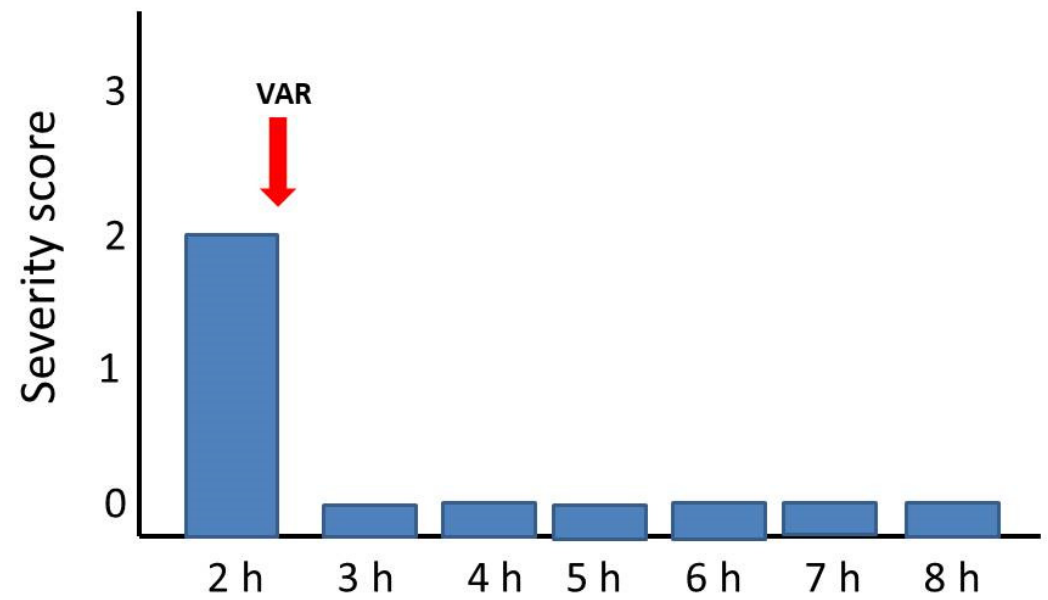

Figure 2. Reversion of paralytic manifestations in groups of four mice receiving three $\mathrm{LD}_{50} \mathrm{~s}$ of Bungarus multicinctus venom. A single bolus dose of LY315920 (10 mg/kg i.v.) (VAR) was administered at the time indicated by the red arrow, when mice showed paralytic manifestations corresponding to a severity score of 2. Paralysis was completely reversed for the following $6 \mathrm{~h}$. 


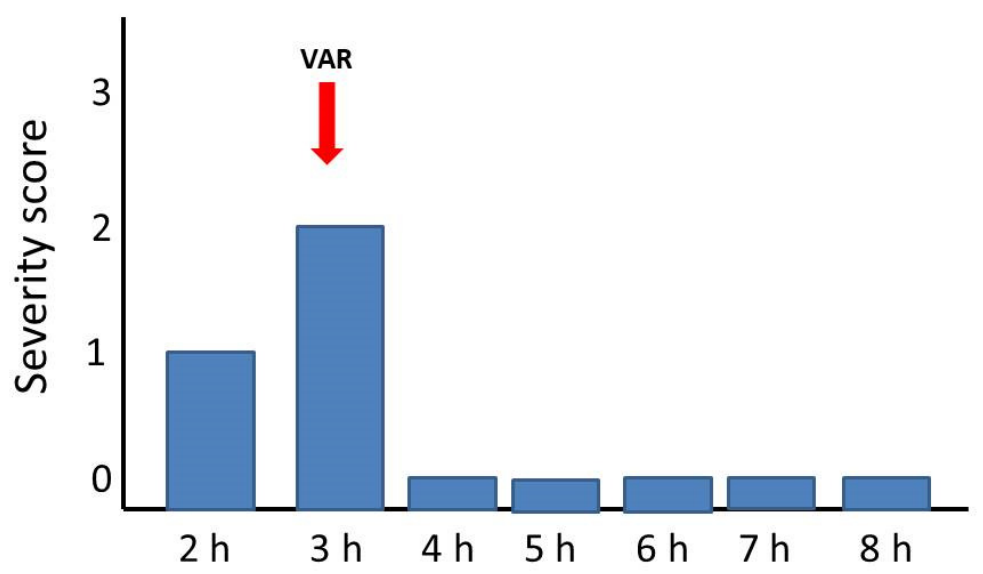

Figure 3. Reversion of paralytic manifestations in groups of four mice receiving $12 \mathrm{LD}_{50} \mathrm{~s}$ of Oxyuranus scutellatus venom by the subcutaneous route. A single bolus dose of LY315920 (10 mg/kg i.v.) (VAR) was administered at the time indicated by the red arrow, when mice showed paralytic manifestations corresponding to a severity score of 2 . Paralysis was completely reversed for the following $5 \mathrm{~h}$.

\subsection{Effect of Neostigmine}

Administration of the anti-cholinesterase drug neostigmine and the anti-muscarinic drug atropine $5 \mathrm{~min}$ before N. scutatus venom injection did not have any effect on the toxicity of the venom, since envenomed mice receiving these drugs and those injected with PBS died at the same time span (2 to $3 \mathrm{~h}$ ). Similar findings were observed in mice receiving neostigmine and atropine before envenoming, and LY315920 immediately after venom injection, as well as in mice receiving only LY315920 after envenoming.

\section{Discussion}

The search for inhibitors that block the action of snake venom toxins, and which could be applied in the field rapidly after the onset of envenoming in a snake bite, has become an area of increasingly active research. In this regard, the search for inhibitors that have been developed for diseases whose pathogenesis is associated with endogenous enzymes, such as $\mathrm{PLA}_{2} \mathrm{~s}$ and metalloproteinases, represents a potentially cost- and development time-efficient piggy-back approach by taking advantage of previous preclinical and clinical assessments of their safety (see for example $[6,24]$ ). Such is the case of the PLA 2 inhibitor Varespladib (LY315920) and its orally available derivative methyl-Varespladib (LY333013), which were developed for the therapy of several unrelated conditions [11,12]. Recent studies have shown the ability of these drugs to inhibit enzymatic PLA $\mathrm{A}_{2}$ activity of a large number of venoms in vitro [7], and to abrogate, in animal models, lethality induced by two neurotoxic elapid venoms whose toxicity is based on the presynaptic action of neurotoxic PLA $\mathrm{A}_{2} \mathrm{~s}[18,19]$.

In order to expand these observations, we have tested the efficacy of the two forms of Varespladib against venoms having presynaptically acting neurotoxic $\mathrm{PLA}_{2} \mathrm{~S}$ of variable quaternary structure, as it is not known how differences in quaternary structure of $\mathrm{PLA}_{2} \mathrm{~S}$ might affect their inhibition by Varespladib. N. scutatus venom contains notexin, a monomeric PLA 2 [25-27]. $\beta$-bungarotoxin, present in the venoms of Bungarus sp, is a dimeric neurotoxin comprising a PLA 2 subunit linked by disulfide bonds to a Kunitz-type proteinase inhibitor [28-30]. The venom of $C$. d. terrificus contains a high proportion of the dimeric neurotoxin crotoxin, comprising a $\mathrm{PLA}_{2}$ subunit linked, through non-covalent bonds, to an enzymatically inactive subunit [31,32]. O. scutellatus venom, in turn, contains the potent presynaptic toxin taipoxin, whose quaternary structure is characterized by three subunits, one of which is a catalytically active PLA $_{2}[27,33]$.

We followed a rescue-type experimental protocol in which venoms were injected s.c., in the hind limb, and the inhibitors were administered at various time intervals either by the i.v. route (LY315920) 
or orally (LY333013), hence simulating a situation where the inhibitors are provided quickly and conveniently after a bite as they might be in a scenario where a person is bitten in a resource limited environment. In the cases of venoms of $N$. scutatus, C. d. terrificus, B. multicinctus, the selected dose of three $\mathrm{LD}_{50} \mathrm{~s}$ induced lethality within $3 \mathrm{~h}$, whereas in the case of $O$. scutellatus, mice receiving three $\mathrm{LD}_{50} \mathrm{~s}$ died within $6 \mathrm{~h}$. Therefore, with this venom we also used a higher challenge dose $\left(12 \mathrm{LD}_{50} \mathrm{~s}\right)$ in order to shorten the survival time to $3 \mathrm{~h}$, and also because this dose had been used in a previous study [18].

Administration of the inhibitors at the various schedules used resulted in a significant delay in the time of death in the cases of the venoms of $C$. d. terrificus and B. multicinctus, and in a complete protection during $24 \mathrm{~h}$ for the venom of $O$ scutellatus, provided the inhibitors were administered at various time intervals after envenoming. These observations underscore the role of neurotoxic $\mathrm{PLA}_{2} \mathrm{~s}$ in the overall toxicity of these three venoms. In the case of $B$. multicinctus venom, a puzzling observation was made when using LY315920, i.e., animals were protected when the drug was given $60 \mathrm{~min}$ after envenoming, but not when administered immediately upon venom injection. We hypothesize that this is due to a mismatch between venom toxicokinetics and drug pharmacokinetics. Since LY315920 has a short half-life, it is likely that, when administered at $0 \mathrm{~min}$, its concentration in the body drops by the time $\beta$-bungarotoxin acts on neuromuscular junctions. Such phenomenon was not observed when LY333013 was administered orally, probably because the pharmacokinetics of this form of Varespladib differs, reaching inhibitory levels in the circulation at later time intervals.

In contrast with these three venoms, no protection was observed in the case of $N$. scutatus venom. One possibility to explain this finding has to do with the potential role of post-synaptically acting $\alpha$-neurotoxins present in this venom [34,35]. Our observations with the inhibitor neostigmine, however, do not support this hypothesis, since administration of this anticholinesterase drug did not inhibit or delay lethality by N. scutatus in our experimental setting. An alternative explanation emerges from the observation that LY315920 is able to significantly delay the lethality when incubated with the venom before injection, hence supporting the view that neurotoxic $\mathrm{PLA}_{2} \mathrm{~s}$, such as notexin, are indeed responsible for this venom's toxicity. Hence, the lack of efficacy of Varespladib when injected after the onset of envenoming could be related to a mismatch of neurotoxic PLA 2 toxicokinetics and LY315920 pharmacokinetics. These are issues of practical and academic interest that deserve further investigation. The complexity of snake venom-induced neurotoxicity [36], the species-to-species variation in the presence of $\mathrm{PLA}_{2}$ neurotoxins, and the toxicokinetic/pharmacokinetic relationships demand innovation and attention in detail in the methods of preclinical assessment of efficacy of toxin specific inhibitors for different snake venoms.

The observation, in the venoms of C.d. terrificus and B. multicinctus, that lethality was not completely prevented but only delayed might have also to do with the mismatch between the pharmacokinetics of the inhibitor and the toxicokinetics of the neurotoxins, since the former is likely to have a shorter half-life than the latter. These drawbacks can be solved by implementing a treatment protocol based on continuous rate infusion of the inhibitor at lower doses, with or without initial bolus administration, as demonstrated in a pig model of envenoming by the venom of the coral snake Micrurus fulvius [19]. Similarly, studies of these types of molecules, with and without antivenom, administered at different times and orders of administration should shed light on the most effective therapeutic protocols.

The recovery from severe neurotoxic paralysis of envenomed mice by the i.v. administration of LY315920 is noteworthy. Studies on the mechanism of action of presynaptically acting snake venom neurotoxic $\mathrm{PLA}_{2}$ s have shown drastic ultrastructural alterations at the nerve terminal, hence explaining the observed lack of efficacy of therapeutic antivenoms when administered after the onset of neurotoxicity [29]. Our findings underscore that Varespladib is able to reverse neurotoxic manifestations in the cases of $C$. d. terrificus, B. multicinctus, and O. scutellatus venoms. In the case of O. scutellatus venom, it abrogates toxicity even at a time when antivenom is largely ineffective in a mouse experimental model [18]. The basis of these intriguing observations is unclear at present, but suggests that this inhibitor has significant therapeutic potential in neurotoxic snakebite envenomings, 
even after the onset of paralysis, and could become a useful experimental tool to further understand the molecular and cellular basis of $\mathrm{PLA}_{2}$-induced neurotoxicity.

It has been proposed that neurotoxic venom $\mathrm{PLA}_{2} \mathrm{~S}$ initially bind to a receptor at the nerve terminal, a step followed by enzymatic hydrolysis of phospholipids in the plasma membrane of the terminal. This in turn causes a calcium influx that promotes the release of the neurotransmitter stored in synaptic vesicles and the increment in the membrane permeability to ions which, in the particular case of calcium, causes the degeneration of the nerve terminal and the irreversible blockade of the transmission [37]. Other studies have provided evidence for an internalization of these neurotoxins into the nerve terminal cytoplasm, with the possible binding to intracellular receptors and the consequent toxicity secondary to hydrolysis of membranes of organelles, such as those of mitochondria [38]. It is possible that these mechanisms are not mutually exclusive, depending on the toxin concentration at the synaptic site, i.e., a threshold phenomenon.

In this mechanistic scenario, the observed ability of LY315920 to reverse paralytic manifestations may be based on (a) the ability of the inhibitor to dissociate the binding of the toxins to their membrane receptor, owing to the high affinity of Varespladib for the $\mathrm{PLA}_{2} \mathrm{~s}$, before extensive phospholipid hydrolysis has occurred and prior to the internalization of the toxin into the nerve terminal; or (b) Varespladib may cross the plasma membrane of the nerve terminal, thus being able to bind the toxins inside the motor neuron, blocking their intracellular degenerative action. Antivenom antibodies are not able to reach the toxins once they are internalized in the nerve terminal, hence providing an explanation for the previously described difference in the ability to reverse toxicity between Varespladib and antivenom when treatment is delayed [18].

In conclusion, LY315920 and LY333013 are effective at delaying or abrogating lethality in a mouse model of envenoming by C. d. terrificus, B. multicinctus, and O. scutellatus. Moreover, LY315920 is able to reverse paralytic manifestations in severely envenomed mice. These results provide further support to the concept that Varespladib could be a valuable novel therapy in envenomings by neurotoxic snake venoms whose predominant mechanism of action is based on the presynaptic action of neurotoxic $\mathrm{PLA}_{2} \mathrm{~S}$ of varying quaternary structure. This proof of concept study did not attempt to optimize dose, dosage form or schedule of administration of these drugs. These and other important issues deserve further investigation.

\section{Materials and Methods}

\subsection{Venoms}

The venom of Oxyuranus scutellatus was obtained from adult specimens collected in Papua New Guinea and supplied by the University of Melbourne. The venom of Crotalus durissus terrificus from Brazil was provided by Instituto Butantan. The venom of Notechis scutatus was purchased from Venom Supplies Pty Ltd. (Tanunda, Australia) and the venom of Bungarus multicinctus was purchased from Latoxan (Portes-lès-Valence, France). These freeze-dried samples were kept at $-20{ }^{\circ} \mathrm{C}$ until use. For the experiments, venoms were dissolved in $0.12 \mathrm{M} \mathrm{NaCl}, 0.04 \mathrm{M}$ phosphate, $\mathrm{pH} 7.2$ (PBS) and fresh solutions were prepared for each experiment.

\subsection{Drugs}

LY315920 and LY333013 were provided by Ophirex, Inc., Corte Madera, CA, USA. LY333013 was converted to LY315920 by ChemieTek (Indianapolis, IN, USA). LY315920 was dissolved in PBS for i.v. administration, and LY333013 was dissolved in 8\% (w/v) gum arabic (Sigma-Aldrich, St. Louis, MO, USA), and was administered orally, as previously described [18]. For both forms of Varespladib, the dose used was $10 \mathrm{mg} / \mathrm{kg}$. This dose was selected on the basis of previous preclinical and clinical data $[11,18]$. 


\subsection{Rescue Experiments and Observations on Lethality}

\subsubsection{Estimation of Subcutaneous Median Lethal Dose (LD50)}

For all the in vivo experiments done in this study, CD-1 mice weighing 18-20 g were used. For each venom, solutions containing various doses of venom were prepared, using PBS as solvent. Groups of four mice were injected subcutaneously (s.c.) in the thigh, as to simulate a typical snake bite, with $100 \mu \mathrm{L}$ containing several doses of venoms. The number of dead mice was recorded at $24 \mathrm{~h}$, and $\mathrm{LD}_{50}$ was estimated by probit analysis [39]. In the case of O. scutellatus venom, the s.c. LD $_{50}$ had been previously determined [23], and the same venom batch of a previous study [18] was used in this work. The protocols of experiments involving the use of mice were approved by the Institutional Committee for the Use and Care of Animals (CICUA) of the University of Costa Rica (CICUA 27-14; 15 July 2014) and met the International Guiding Principles for Biomedical Research involving Animals (CIOMS).

\subsubsection{Rescue Experiments}

Groups of four mice received a s.c. injection of a dose of the venoms corresponding to three $\mathrm{LD}_{50} \mathrm{~s}$. In the case of venom of $O$. scutellatus, a challenge dose of $12 \mathrm{LD}_{50} \mathrm{~s}$ was also used in order to follow the protocol of a previous study with this venom [18]. Immediately after venom injection, or at various time intervals after envenoming (see details in tables), a dose of $10 \mathrm{mg} / \mathrm{kg}$ of either LY315920 (i.v. in the caudal vein in a volume of $200 \mu \mathrm{L}$ PBS) or LY333013 (orally in a volume of $200 \mu \mathrm{L}$ gum arabic) was administered. Control mice were injected with venom and with either PBS i.v. or received gum arabic by the oral route instead of the inhibitors. Deaths were recorded at $3 \mathrm{~h}, 6 \mathrm{~h}$, and $24 \mathrm{~h}$ after envenoming.

In the case of the venom of $O$. scutellatus, for which the inhibitors provided full protection during $24 \mathrm{~h}$ (see Results), the median inhibitory dose ( $\left.\mathrm{ID}_{50}\right)$ was estimated. For this, groups of mice received a subcutaneous injection of a dose of venom corresponding to $12 \mathrm{LD}_{50} \mathrm{~s}$ and then, immediately after envenoming, the following doses of LY315920 were administered i.v. in the caudal vein: $10 \mathrm{mg} / \mathrm{kg}$, $5 \mathrm{mg} / \mathrm{kg}, 2.5 \mathrm{mg} / \mathrm{kg}$, and $1.25 \mathrm{mg} / \mathrm{kg}$, in a volume of $200 \mu \mathrm{L}$ PBS. Control mice received venom and $200 \mu \mathrm{L}$ PBS instead of the inhibitor. Deaths were recorded at $24 \mathrm{~h}$ and ID $_{50}$ was estimated by probit analysis [39]. In the case of N. scutatus, owing to the lack of effect of the inhibitors when administered after venom injection (see Results), experiments in which LY315920 was incubated with venom prior to injection were carried out. A solution of venom $(135 \mu \mathrm{g} / \mathrm{mL})$ and inhibitor $(400 \mu \mathrm{M})$ was prepared in a volume of $1.0 \mathrm{~mL}$, and incubated at $37^{\circ} \mathrm{C}$ for $30 \mathrm{~min}$. Then, aliquots of $100 \mu \mathrm{L}$ the mixture, containing three $\mathrm{LD}_{50} \mathrm{~s}$ of venom, were injected s.c. into a group of four mice. Controls included animals receiving three $\mathrm{LD}_{50}$ of venom alone. Lethality was recorded at various time intervals.

\subsubsection{Reversal of Paralytic Effects}

In order to assess whether the inhibitors are able to reverse the neurotoxic (paralytic) manifestations of envenoming once they have been established, a semi-quantitative toxicity scale for assessing the extent of paralysis was used. In this scale, 0 corresponds to a complete absence of paralysis; 1 corresponds to either paralysis in the hind limbs or respiratory difficulty (forceful respiration); 2 corresponds to both paralysis in the hind limbs and respiratory difficulty; and 3 corresponds to complete paralysis of both hind limbs and fore limbs and respiratory difficulty. When mice were in a degree of envenoming corresponding to grades 2 or 3, a single bolus dose of $10 \mathrm{mg} / \mathrm{kg}$ of the inhibitor LY315920, dissolved in $200 \mu \mathrm{L}$ PBS, was administered i.v. Mice were observed every hour thereafter, for a period of $8 \mathrm{~h}$, and the severity of paralysis was assessed following the described scale.

\subsection{Inhibitory Effect of Neostigmine}

In the case of the venom of N. scutatus, in order to assess the possible role of post-synaptically acting $\alpha$-neurotoxins in lethality, the inhibitory effect of neostigmine was assessed alone or in combination with Varespladib. This drug inhibits acetylcholinesterase, hence increasing the concentration of acetylcholine at the neuromuscular junction. Atropine was administered in conjunction of neostigmine in order 
to avoid the muscarinic effects of neostigmine. Various groups of four mice received the following treatments: (a) s.c. injection of neostigmine $(50 \mathrm{mg} / \mathrm{kg})$ and atropine $(50 \mathrm{mg} / \mathrm{kg})$ (Sigma-Aldrich, St. Louis, MO, USA) 5 min before the s.c. injection of three $\mathrm{LD}_{50} \mathrm{~s}$ of $N$. scutatus venom; (b) s.c. injection of neostigmine and atropine 5 min before envenoming, and i.v. administration of LY315920 immediately after the s.c. injection of venom; (c) i.v. administration of LY315920 immediately after the s.c. injection of venom; (d) i.v. administration of PBS immediately after s.c. venom injection. Animals were then observed for lethality.

Author Contributions: Conceptualization, J.M.G., M.R.L., D.J.W.; methodology: J.M.G., B.L.; investigation: J.M.G., B.L.; data analysis: J.M.G., M.R.L., D.J.W., B.L.; writing-original draft preparation: J.M.G.; writing-review: J.M.G.; M.R.L., D.J.W., B.L. All authors have read and agreed to the published version of the manuscript.

Funding: This research was funded by Vicerrectoría de Investigación, Universidad de Costa Rica. DJW was funded by a Doherty Biomedical Fellowship (GNT1109575) from the Australian National Health and Medical Research Council.

Acknowledgments: Thanks are due to Daniela Solano and Wendy Bryan-Quirós (Instituto Clodomiro Picado) for their collaboration in the laboratory work.

Conflicts of Interest: JMG, DJW, BL have no competing interests to disclose. MRL has stock and is a salaried director at Ophirex, Inc., a Public Benefit Corporation.

\section{References}

1. Gutiérrez, J.M.; Calvete, J.J.; Habib, A.G.; Harrison, R.A.; Williams, D.J.; Warrell, D.A. Snakebite envenoming. Nat. Rev. Dis. Primers 2017, 3, 17079. [CrossRef]

2. World Health Organization. Snakebite Envenoming, A Strategy for Prevention and Control; World Health Organization: Geneva, Switzerland, 2019; pp. 1-50.

3. Warrell, D.A. Snake bite. Lancet 2010, 375, 77-88. [CrossRef]

4. Gutiérrez, J.M.; Lomonte, B.; León, G.; Rucavado, A.; Chaves, F.; Angulo, Y. Trends in snakebite envenomation therapy: Scientific, technological and public health considerations. Curr. Pharm. Des. 2007, 13, 2935-2950. [CrossRef] [PubMed]

5. Rucavado, A.; Escalante, T.; Franceschi, A.; Chaves, F.; León, G.; Cury, Y.; Ovadia, M.; Gutiérrez, J.M. Inhibition of local hemorrhage and dermonecrosis induced by Bothrops asper snake venom: Effectiveness of early in situ administration of the peptidomimetic metalloproteinase inhibitor batimastat and the chelating agent $\mathrm{CaNa}_{2}$ DTA. Am. J. Trop. Med. Hyg. 2000, 63, 313-319. [CrossRef] [PubMed]

6. Arias, A.S.; Rucavado, A.; Gutiérrez, J.M. Peptidomimetic hydroxamate metalloproteinase inhibitors abrogate local and systemic toxicity induced by Echis ocellatus (saw-scaled) snake venom. Toxicon 2017, 132, 40-49. [CrossRef] [PubMed]

7. Lewin, M.; Samuel, S.; Merkel, J.; Bickler, P. Varespladib (LY315920) appears to be a potent, broad-spectrum, inhibitor of snake venom phospholipase A2 and a possible pre-referral treatment for envenomation. Toxins 2016, 8, 248. [CrossRef] [PubMed]

8. Chen, Y.J.; Tsai, C.Y.; Hu, W.P.; Chang, L.S. DNA aptamers against Taiwan banded krait $\alpha$-bungarotoxin recognize Taiwan cobra cardiotoxins. Toxins 2016, 8, 66. [CrossRef]

9. O’Brien, J.; Lee, S.H.; Gutiérrez, J.M.; Shea, K.J. Engineered nanoparticles bind elapid snake venom toxins and inhibit venom-induced dermonecrosis. PLoS Negl. Trop. Dis. 2018, 12, e0006736. [CrossRef]

10. Albulescu, L.O.; Kazandjian, T.; Slagboom, J.; Bruyneel, B.; Ainsworth, S.; Alsolaiss, J.; Wagstaff, S.C.; Whiteley, G.; Harrison, R.A.; Ulens, C.; et al. A decoy-receptor approach using nicotinic acetylcholine receptor mimics reveals their potential as novel therapeutics against neurotoxic snakebite. Front. Pharmacol. 2019, 10, 848. [CrossRef]

11. Adis, R.; Profile, D. Varespladib. Am. J. Cardiovasc. Drugs 2011, 11, 137-143.

12. Nicholls, S.J.; Kastelein, J.P.; Schwartz, G.G.; Bash, D.; Rosenson, R.S.; Cavender, M.A.; Brennan, M.S.; Koenig, W.; Jukema, W.; Nambi, V.; et al. Varespladib and cardiovascular events in patients with an acute coronary syndrome. The VISTA-16 randomized clinical trial. JAMA 2014, 311, 252-262. [CrossRef] [PubMed]

13. Kini, R.M. Excitement ahead: Structure, function and mechanism of snake venom phospholipase $\mathrm{A}_{2}$ enzymes. Toxicon 2003, 42, 827-840. [CrossRef] [PubMed] 
14. Calvete, J.J.; Sanz, L.; Cid, P.; de la Torre, P.; Flores-Díaz, M.; dos Santos, M.C.; Borges, A.; Bremo, A.; Angulo, Y.; Lomonte, B.; et al. Snake venomics of the Central American rattlesnake Crotalus simus and the South American Crotalus durissus complex points to neurotoxicity as an adaptive paedomorphic trend along Crotalus dispersal in South America. J. Proteome Res. 2010, 9, 528-544. [CrossRef] [PubMed]

15. Herrera, M.; Fernández, J.; Vargas, M.; Villalta, M.; Segura, Á.; León, G.; Angulo, Y.; Paiva, O.; Matainaho, T.; Jensen, S.D.; et al. Comparative proteomic analysis of the venom of the taipan snake, Oxyuranus scutellatus, from Papua New Guinea and Australia: Role of neurotoxic and procoagulant effects in venom toxicity. J. Proteom. 2012, 75, 2128-2140. [CrossRef] [PubMed]

16. Lomonte, B.; Fernández, J.; Sanz, L.; Angulo, Y.; Sasa, M.; Gutiérrez, J.M.; Calvete, J.J. Venomous snakes of Costa Rica: Biological and medical implications of their venom proteomic profiles analyzed through the strategy of snake venomics. J. Proteom. 2014, 105, 323-339. [CrossRef]

17. Tasoulis, T.; Isbister, G.F. A review and database of snake venom proteomes. Toxins 2017, 9, 290. [CrossRef]

18. Lewin, M.R.; Gutiérrez, J.M.; Samuel, S.P.; Herrera, M.; Bryan-Quirós, W.; Lomonte, B.; Bickler, P.E.; Bulfone, T.C.; Williams, D.J. Delayed oral LY333013 rescues mice from highly neurotoxic, lethal doses of Papuan Taipan (Oxyuranus scutellatus) venom. Toxins 2018, 10, E380. [CrossRef]

19. Lewin, M.R.; Gilliam, L.L.; Gilliam, J.; Samuel, S.P.; Bulfone, T.C.; Bickler, P.E.; Gutiérrez, J.M. Delayed LY333013 (oral) and Ly315920 (intravenous) reverse severe neurotoxicity and rescue juvenile pigs from lethal doses of Micrurus fulvius (Eastern coral snake) venom. Toxins 2018, 10, E479. [CrossRef]

20. Bryan-Quirós, W.; Fernández, J.; Gutiérrez, J.M.; Lewin, M.R.; Lomonte, B. Neutralizing properties of LY315920 toward snake venom group I and II myotoxic phospholipases $A_{2}$. Toxicon 2019, 157, 1-7. [CrossRef]

21. Salvador, G.H.M.; Gomes, A.A.S.; Bryan-Quirós, W.; Fernández, J.; Lewin, M.R.; Gutiérrez, J.M.; Lomonte, B.; Fontes, M.R.M. Structural basis for phospholipase $\mathrm{A}_{2}$-like toxin inhibition by the synthetic compound Varespladib (LY315920). Sci. Rep. 2019, 9, 17203. [CrossRef]

22. Bittenbinder, M.A.; Zdenek, C.N.; Op den Brouw, B.; Youngman, N.J.; Dobson, J.S.; Naude, A.; Vonk, F.J.; Fry, B.G. Coagulotoxic cobras: Clinical implications of strong anticoagulant actions of African spitting Naja venoms that are not neutralized by antivenom but are by LY315920 (Varespladib). Toxins 2018, 10, 516. [CrossRef] [PubMed]

23. Herrera, M.; Collaço, R.C.O.; Villalta, M.; Segura, Á.; Vargas, M.; Wright, C.E.; Paiva, O.; Matainaho, T.; Jensen, S.D.; León, G.; et al. Neutralization of the neuromuscular inhibition of venom and taipoxin from the taipan (Oxyuranus scutellatus) by $\mathrm{F}\left(\mathrm{ab}^{\prime}\right)_{2}$ and whole IgG antivenoms. Toxicol. Lett. 2016, 241, 175-183. [CrossRef] [PubMed]

24. Bulfone, T.C.; Samuel, S.P.; Bickler, P.E.; Lewin, M.R. Developing small molecule therapeutics for the initial and adjunctive treatment of snakebite. J. Trop. Med. 2018, 4320175. [CrossRef] [PubMed]

25. Karlsson, E.; Eaker, D.; Rydén, L. Purification of a neurotoxin from the venom of the Australian tiger snake Notechis scutatus. Toxicon 1972, 10, 405-413. [CrossRef]

26. Halpert, J.; Eaker, D. Amino acid sequence of a presynaptic neurotoxin from the venom of Notechis scutatus scutatus (Australian tiger snake). J. Biol. Chem. 1975, 250, 6990-6997. [PubMed]

27. Harris, J.B.; Grubb, B.D.; Maltin, C.A.; Dixon, R. The neurotoxicity of the venom phospholipases $\mathrm{A}_{2}$ notexin and taipoxin. Exp. Neurol. 2000, 161, 517-526. [CrossRef] [PubMed]

28. Kondo, K.; Narita, K.; Lee, C.Y. Amino acid sequences of the two polypeptide chains of $\beta 1$-bungarotoxin from the venom of Bungarus multicinctus. J. Biochem. 1978, 83, 101-115. [CrossRef]

29. Dixon, R.W.; Harris, J.B. Nerve terminal damage by $\beta$-bungarotoxin: Its clinical significance. Am. J. Pathol. 1999, 154, 447-455. [CrossRef]

30. Sunegar, K.; Jackson, T.N.W.; Reeks, T.; Fry, B.G. Group I phospholipase $\mathrm{A}_{2}$ enzymes. In Venomous Reptiles and Their Toxins. Evolution, Pathophysiology \& Biodiscovery; Fry, B.G., Ed.; Oxford University Press: Oxford, UK, 2015; pp. 327-334.

31. Faure, G.; Xu, H.; Saul, F.A. Crystal structure of crotoxin reveals key residues involved in the stability and toxicity of this potent heterodimeric $\beta$-neurotoxin. J. Mol. Biol. 2011, 412, 176-191. [CrossRef]

32. Gopalakrishnakone, P.; Hawgood, B.J. Morphological changes induced by crotoxin in murine nerve and neuromuscular junction. Toxicon 1984, 22, 791-804. [CrossRef]

33. Fohlman, J.; Eaker, D.; Karlsson, E.; Thesleff, S. Taipoxin, an extremely ptent presynaptic neurotoxin from the venom of the Australian snake taipan (Oxyuranus s. scutellatus). Isolation, characterization, quaternary structure and pharmacological properties. Eur. J. Biochem. 1976, 68, 457-469. [CrossRef] [PubMed] 
34. Halpert, J.; Fohlman, J.; Eaker, D. Amino acid sequence of a postsynaptic neurotoxin from the venom of the Australian tiger snake Notechis scutatus scutatus. Biochimie 1979, 61, 719-723. [CrossRef]

35. Tan, C.H.; Tan, K.Y.; Tan, N.H. Revisiting Notechis scutatus venom: On shotgun proteomics and neutralization by the "bivalent" Sea Snake Antivenom. J. Proteom. 2016, 144, 33-38. [CrossRef] [PubMed]

36. Ranawaka, U.K.; Lalloo, D.G.; de Silva, H.J. Neurotoxicity in snakebite. The limits of our knowledge. PLoS Negl. Trop. Dis. 2013, 7, e2302. [CrossRef] [PubMed]

37. Montecucco, C.; Gutiérrez, J.M.; Lomonte, B. Cellular pathology induced by snake venom phospholipase $\mathrm{A}_{2}$ myotoxins and neurotoxins: Common aspects of their mechanisms of action. Cell. Mol. Life Sci. 2008, 65, 2897-2912. [CrossRef]

38. Šribar, J.; Oberčkal, J.; Križaj, I. Understanding the molecular mechanisms underlying the presynaptic toxicity of secreted phospholipases $\mathrm{A}_{2}$ : An update. Toxicon 2014, 89, 9-16. [CrossRef]

39. Finney, D.J. Probit Analysis; Cambridge University Press: Cambridge, UK, 1971.

(C) 2020 by the authors. Licensee MDPI, Basel, Switzerland. This article is an open access article distributed under the terms and conditions of the Creative Commons Attribution (CC BY) license (http://creativecommons.org/licenses/by/4.0/). 